\title{
Modifikasi Mesin Pencampur Bahan Pakan Ternak
}

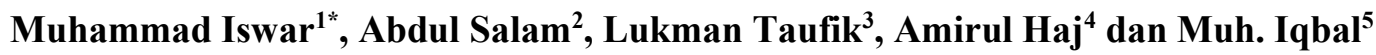 \\ 1,2,3,4,5 Jurusan Teknik Mesin, Politeknik Negeri Ujung Pandang, Makassar 90245, Indonesia \\ *muh_iswar@poliupg.ac.id
}

\begin{abstract}
This modification was made to improve the quality of mixing animal feed ingredients to be more evenly distributed and efficient mixing time. By developing the system of rotation power transfer (transmission) is more stable because there is no slip anymore than the previous engine using the v-belt transmission system. With modifications to the design of this machine can make it easier for farmers to move the machine. The results obtained indicate that the mixing of animal feed ingredients was evenly distributed for one time the mixing process of $16 \mathrm{~kg}$ was achieved in 5 minutes with a rotation of $65 \mathrm{Rpm}$ or a mixing capacity of $192 \mathrm{~kg} / \mathrm{hour}$, compared to the previous machine which gets uniform results at a rotation of $70 \mathrm{Rpm}$ with a mixing time of 5 minutes, or a mixing capacity of $180 \mathrm{~kg} / \mathrm{hour}$. The cost used in the assembly of this animal feed mixing machine is worth Rp. 5,520,033.-
\end{abstract}

Keywords: Modification; Machine; Blender; Feed; Livestock

\begin{abstract}
Abstrak: Modifikasi ini dilakukan untuk meningkatkan kualitas pencampuran bahan pakan ternak agar lebih merata dan waktu pencampuran yang efisisen. Dengan melakukan pengembangan pada sistem pemindah daya (transmisi) putaran lebih stabil karena tidak terjadi lagi slip dibandingkan mesin sebelumnya yang menggunakan sistem transmisi v-belt. Dan dengan modifikasi desain mesin ini bisa memudahkan peternak untuk memindah tempatkan mesin tersebut. Hasil yang diperoleh menunjukkan bahwa pencampuran bahan pakan ternak sudah merata untuk satu kali proses pencampuran sebanyak $16 \mathrm{~kg}$ dicapai pada waktu 5 menit dengan putaran $65 \mathrm{Rpm}$ atau kapasitas pencampuran $192 \mathrm{~kg} / \mathrm{jam}$, dibandingkan dengan mesin sebelumnya yang mendapatkan hasil yang merata pada putaran $70 \mathrm{Rpm}$ dengan waktu pencampuran 5 menit, atau kapasitas pencampuran sebanyak 180 $\mathrm{kg} / \mathrm{jam}$. Adapun biaya yang digunakan dalam perakitan mesin pencampur bahan pakan ternak ini yakni senilai Rp. 5.520.033,-
\end{abstract}

Kata kunci : Modifikasi; Mesin; Pencampur; Pakan; Ternak

\section{PENDAHULUAN}

Usaha peternakan yang banyak ditekuni oleh masyarakat di daerah adalah peternakan jenis unggas seperti ayam, burung, dan berbagai jenis unggas lainnya. Namun demikian, kendala yang dirasakan peternak adalah terbatasnya pakan ternak yang murah. Sampai saat ini pakan ternak yang ada di Sulawesi Selatan sebagian masih diimpor dari negara lain dengan harga yang cukup tinggi dan sebagian lainnya didatangkan dari pulau Jawa yang juga dirasakan peternak masih cukup mahal. Bila peternak unggas menggunakan pakan ternak yang mahal tentunya akan menambah biaya operasi produksi sehingga akan mengurangi pendapatannya.

Berbagai terobosan telah dilakukan terkait dengan kendala yang dirasakan peternak misalnya, dengan merancang mesin pencampur bahan pakan ternak akan tetapi hasil proses pencampuran bahan pakan ternak yang kurang merata bila dibandingkan pakan yang dibeli di pabrik pembuat pakan serta membutuhkan waktu yang relatif lebih lama dalam satu kali proses pencampuran (proses yang dibutuhkan sekitar setengah jam). Kapasitas pencampuran bahan pakan yang dihasilkan hanya sekitar $50 \mathrm{~kg} / \mathrm{jam}$ untuk dua sampai tiga kali proses [1].

Hal ini disebabkan karena beberapa komponen alat masih kurang menunjang proses pencampuran, antara lain poros spiral terlalu kecil sehingga pakan yang terangkat sedikit, bak penampung pakan juga kecil sehingga bahan pakan yang dicampur juga sedikit. Disamping itu, 
terdapat kelemahan mendasar pada sistem transmisi dimana putaran motor rendah sehingga sangat lambat dalam mencampur bahan pakan.

Ada juga yang telah membuat rancang bangun mesin pencampur pakan ternak dimana desain konstruksi yang dapat memutar wadah penampung pakan dalam arah vertikal namun mesin tersebut juga masih memiliki beberapa kekurangan seperti pelat pengaduk pada bagian bawah bak penampung kurang maksimal sehingga terdapat bahan pakan ternak yang belum tercampur merata pada bagian bawah bak penampung. Selain itu, mesin ini hanya dapat digunakan ditempat yang mempunyai aliran listrik [2].

Namun masih terdapat kekurangan pada mesin tersebut, seperti tergolong berat sehingga membutuhkan tenaga lebih dari satu orang untuk memindahkannya, sehingga perbaikan juga dilakukan agar diperoleh mesin pencampur bahan pakan ternak yang ringan dalam pengoperasiannya [3]. Perbaikan selanjutnya, dibutuhkan roda untuk mempermudah pemindahan mesin. Selain itu, mesin juga kadang mengalami slip pada sistem transmisi antara poros dan pulli yang mengakibatkan rendahnya putaran motor sehingga tidak mampu mengaduk secara merata.

Dari latar belakang diatas maka penulis tertarik untuk mengangkat topik dalam skripsi mengenai judul "Modifikasi Mesin Pencampur Bahan Pakan Ternak" yang diharapkan dapat meningkatkan produktifitas pakan yang dihasilkan dan dapat mengoptimalkan kinerja mesin pencampuran pakan ternak.

Tujuan dari penelitian ini adalah untuk memudahkan peternak dalam memindahkan mesin tersebut serta untuk mencegah terjadinya slip pada sistem transmisi mesin pencampur pakan ternak. Sehingga diperoleh mesin pencampur pakan ternak yang memiliki kinerja yang lebih optimal dan mudah dalam pengoperasian.

Penelitian tentang mesin pencampur pakan ternak telah banyak dilakukan diantaranya adalah dengan melakukan kajian kinerja dari mesin pencampur pakan ternak menggunakan motor dengan daya 0,25 HP [4], juga telah dilakukan perencanaan mesin pencampur pakan ternak dengan bahan pakan ternak yang dicampur adalah rumput dengan tetes tebu yang memiliki kapasitas produksi $750 \mathrm{~kg}$ setiap 15 menit [5], pembuatan pakan ternak dengan bahan limbah cangkang kerang juga telah dilakukan [6], pengembangan desain mesin pencampur bahan pakan ternak juga telah dilakukan [7] dan juga dikembangkan dengan menerapkan crusher and mixing machine pakan ternak dengan berbasis PLC [8].

\section{METODE PENELITIAN}

Adapun metode pada tahap ini akan dilakukan kegiatan meliputi :

1. Membuat gambar rancangan atau desain alat.

2. Memilih bahan untuk setiap komponen yang akan digunakan.

3. Persiapan alat yang akan digunakan.

4. Rencana urutan proses pembuatan dan mesin perkakas yang akan digunakan serta perencanaan alat bantu yang akan digunakan.

Tabel 1. Tahap pembuatan komponen

\begin{tabular}{|c|c|c|c|}
\hline No & Komponen & Alat dan Bahan & Proses Pengujian \\
\hline
\end{tabular}




\begin{tabular}{|c|c|c|c|}
\hline 1. & Rangka & $\begin{array}{l}\text { a. Alat: } \\
\text { - mesin las listrik } \\
\text { - mesin gerinda } \\
\text { - mesin bor } \\
\text { - siku } \\
\text { - mata gerinda } \\
\text { - alat ukur } \\
\text { - spidol warna } \\
\text { - elektroda } \\
\text { b. bahan } \\
\text { - profil U } \\
\text { - profil L }\end{array}$ & $\begin{array}{l}\text { a. potong besi profil L dan profil U sesuai dengan } \\
\text { ukuran menggunakan mesin gerinda. } \\
\text { b. setelah di potong sesuai ukuran, lalu disatukan } \\
\text { atau di rangkai sesuai dengan gambar kerja } \\
\text { dengan cara di las. } \\
\text { c. proses pelubangan pada rangka yang berfungsi } \\
\text { sebagai dudukan mesin dan tempat bantalan } \\
\text { menggunakan mesin bor tangan } \\
\text { d. bersihkan bekas pengelasan dengan } \\
\text { menggunakan mesin gerinda halus. }\end{array}$ \\
\hline 2 . & $\mathrm{B}$ & $\begin{array}{l}\text { a. Alat : } \\
\text { - mesin las listrik } \\
\text { - mesin gerinda } \\
\text { - mesin bor } \\
\text { - mesin rol } \\
\text { - klem } \\
\text { - siku } \\
\text { - alat ukur } \\
\text { - penggores } \\
\text { - mesin pemotong } \\
\text { plat } \\
\text { - elektroda } \\
\text { - mata bor } \\
\text { b. Bahan } \\
\text { - besi plat tebal } \\
\text { 2.5mm } \\
\text { - engsel }\end{array}$ & $\begin{array}{l}\text { a. besi plat dengan tebal } 2.5 \mathrm{~mm} \text { dipotong menjadi } \\
4 \text { bagian yang terdiri dari bak utama, penutup } \\
\text { bak samping kiri dan kanan serta penutup bak } \\
\text { sesuai dengan ukuran yang telah di tentukan } \\
\text { menggunakan mesin pemotong plat } \\
\text { b. potong bak utama di bentuk setengah lingkaran } \\
\text { menggunakan mesin rol. } \\
\text { c. plat penutup samping kiri dan kanan dipotong } \\
\text { menggunakan mesin gerinda hingga berbentuk } \\
\text { setengah lingkaran. kemudian di bor untuk } \\
\text { lubang poros } 1 \text { inch dan baut tempat bantalan. } \\
\text { d. satukan plat utama yang telah di rol dan plat } \\
\text { penutup samping menggunakan mesin las listrik } \\
\text { hingga berbentuk bak penampang pakan. } \\
\text { e. untuk bagian penutupnya plat di potong sesuai } \\
\text { dengan ukuran bak kemudian engsel di las pada } \\
\text { bagian penutup dan bak utama hingga keduanya } \\
\text { menyatu. }\end{array}$ \\
\hline 3. & & $\begin{array}{l}\text { a. Alat } \\
\text { - mesin las listrik } \\
\text { - elektroda stainless } \\
\text { - mesin gerinda } \\
\text { - spidol } \\
\text { - alat ukur } \\
\text { b. Bahan } \\
\text { - plat stainless } \\
\text { - besi as } \\
\text { - pipa stainless }\end{array}$ & $\begin{array}{l}\text { a. potong besi as sesuai ukuran sebanyak } 12 \text { buah, } \\
\text { b. kemudian besi as di las pada pipa stainless } \\
\text { dengan jarak tertentu yang berfungsi sebagai } \\
\text { rangka pengaduk } \\
\text { c. gambar pola model pengaduk yang telah di } \\
\text { rancang pada plat stainless menggunakan } \\
\text { spidol, kemudian potong menggunakan mesin } \\
\text { gerinda mengikuti pola pada plat } \\
\text { d. tahap terakhir plat baja yang telah berbentuk } \\
\text { pola kemudian di las pada rangka pengaduk. }\end{array}$ \\
\hline 4. & Corong pen & $\begin{array}{l}\text { a. Alat } \\
\text { - mesin las listrik } \\
\text { - mesin gerinda } \\
\text { - alat ukur } \\
\text { - pemotong plat } \\
\text { - elektroda ss } \\
\text { b. Bahan } \\
\text { - plat stainless }\end{array}$ & $\begin{array}{l}\text { a. potong plat stainless sesuai dengan ukuran yang } \\
\text { di rencanakan menggunakan mesin pemotong } \\
\text { plat. } \\
\text { b. setelah terbentuk kemudian las hingga } \\
\text { terbentuk suatu corong pengeluaran pakan } \\
\text { c. tahap terakhir gerinda sisa-sisa pengelasan. }\end{array}$ \\
\hline
\end{tabular}

Komponen Standar yang terdapat pada mesin pencampur bahan pakan ternak yaitu:

Tabel 2. Komponen standar yang digunakan

\begin{tabular}{|l|l|l|}
\hline No & Spesifikasi Komponen & Gambar Komponen \\
\hline
\end{tabular}




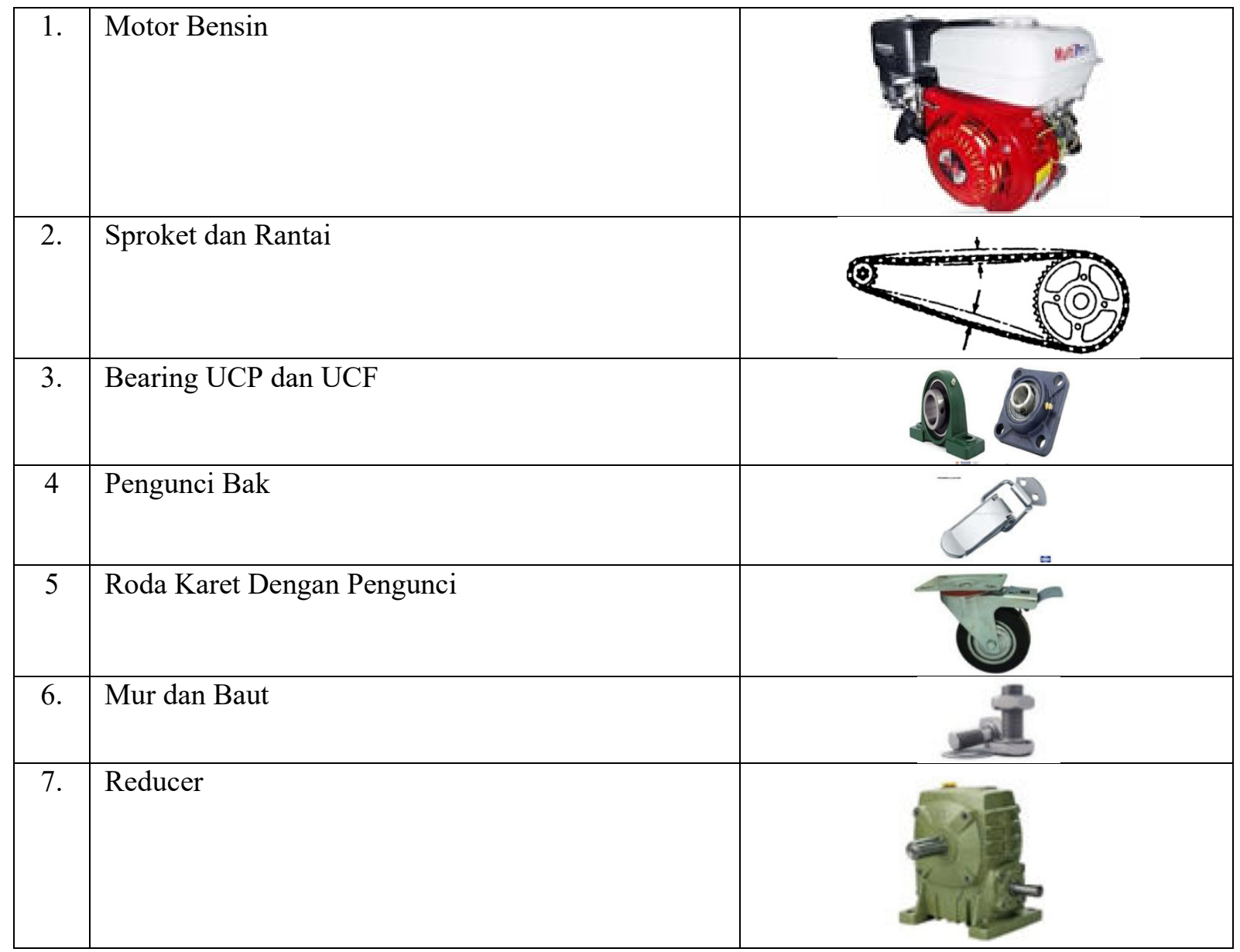


33 Muhammad Iswar, Abdul Salam, Lukman Taufik, Amirul Haj, Muh. Iqbal. Modifikasi Mesin Pencampur Bahan Pakan Ternak

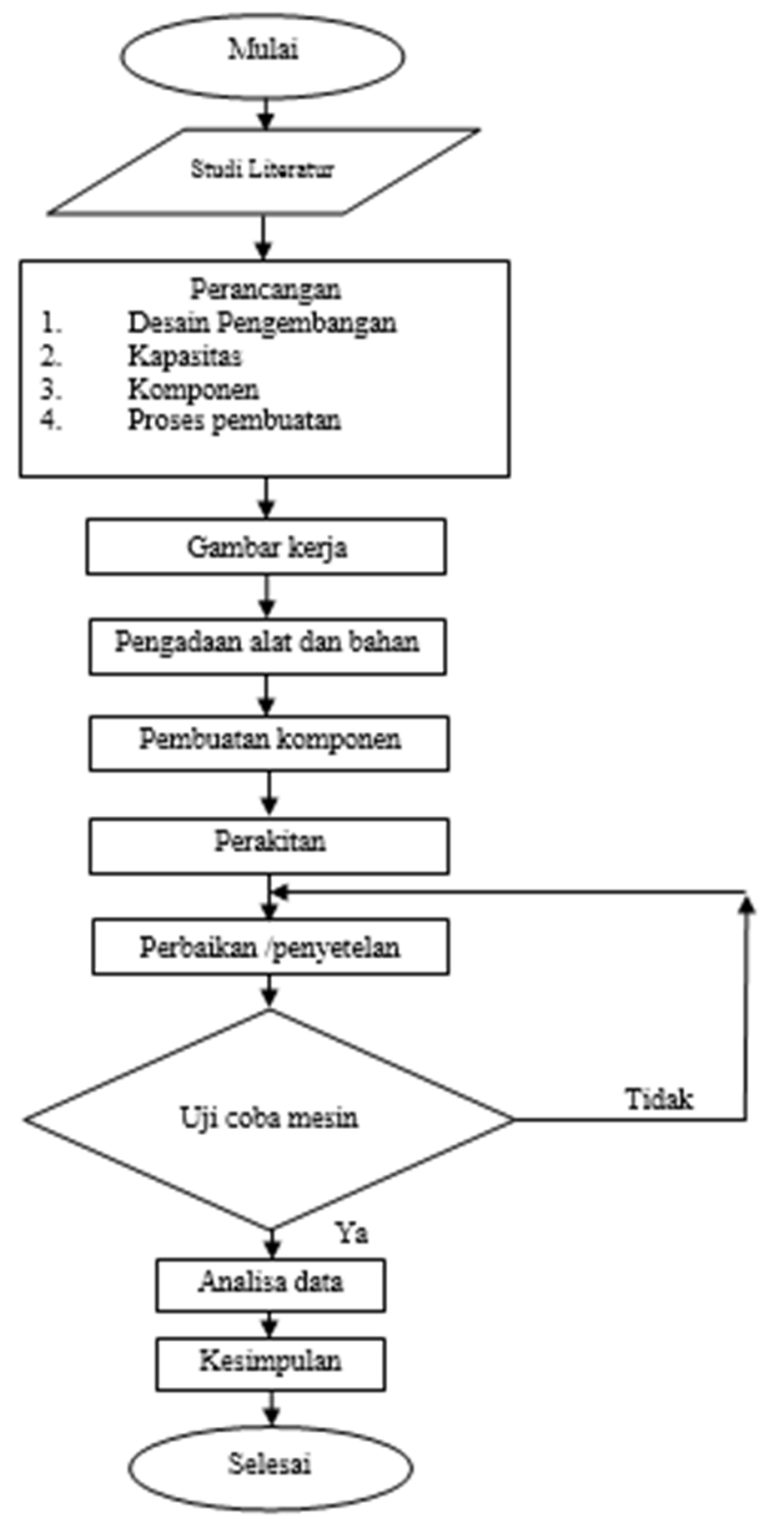

Gambar 1. Alur pengerjaan mesin pencampur pakan ternak

\section{HASIL DAN PEMBAHASAN}

A. Hasil Modifikasi Alat

Berdasarkan alat sebelumnya, adapun hasil modifikasi mesin pencampur bahan pakan ternak yang kami buat adalah sebagai berikut : 


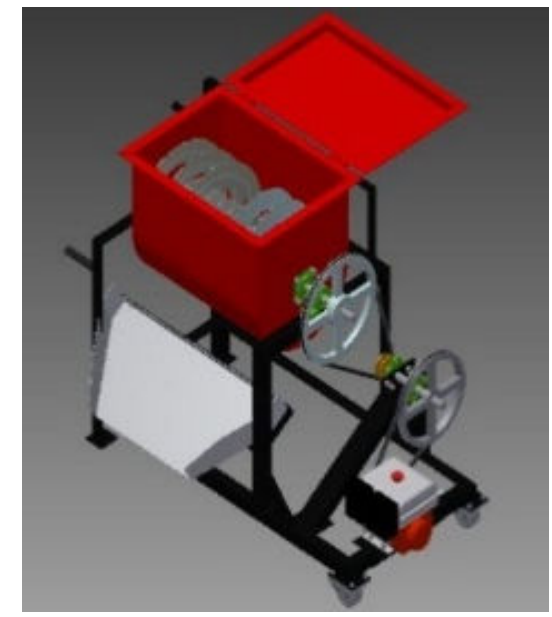

Gambar 2. Desain Sebelumnya

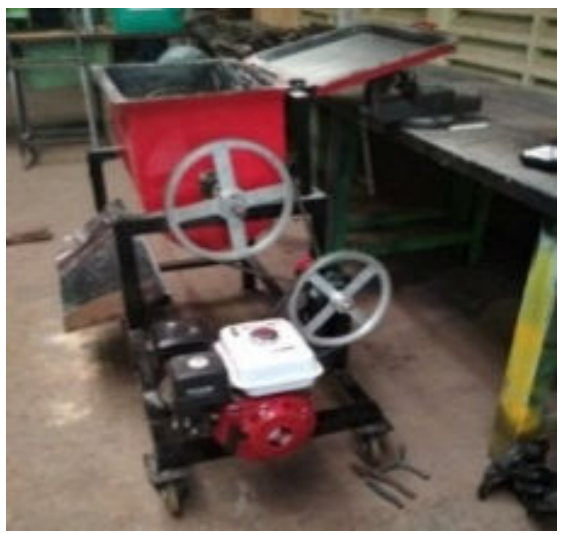

Gambar 3. Gambar alat sebelumnya

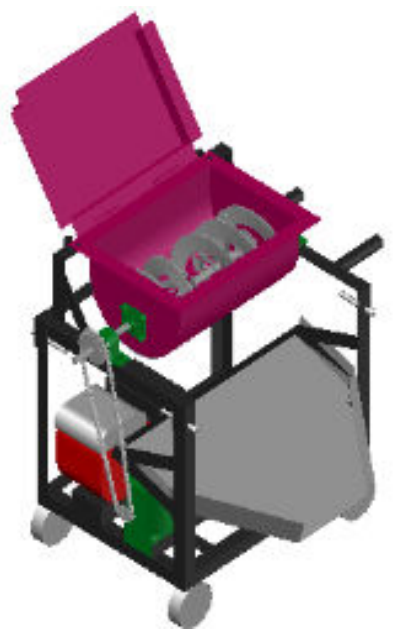

Gambar 4. Desain pengembangan alat 
35 Muhammad Iswar, Abdul Salam, Lukman Taufik, Amirul Haj, Muh. Iqbal. Modifikasi Mesin Pencampur Bahan Pakan Ternak

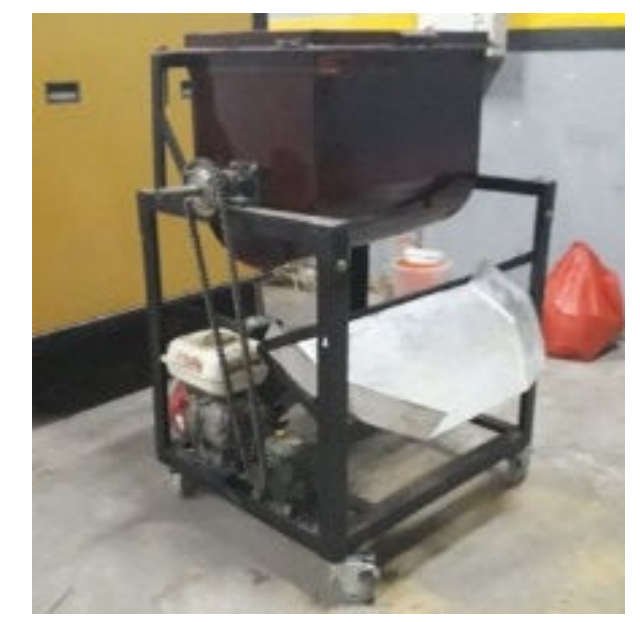

Gambar 5. Hasil Pengembangan Desain Mesin

\section{B. Hasil Perhitungan}

\section{Perhitungan Daya Motor}

Karena belum adanya referensi yang membahas mengenai besarnya gaya lawan pakan, maka kami menganggap bahwa gaya lawan pakan adalah nol (0). Parameter yang kami gunakan adalah massa poros pencampur dan massa pakan yang akan dicampur. Jadi besarnya daya motor dapat dihitung dengan persamaan :

Fs $=$ Gaya yang bekerja pada poros

$$
\mathrm{P}=\frac{\mathrm{Fs} \cdot \mathrm{Vc}}{4500}
$$

$=$ Massa pakan + Massa poros pencampur

$=15 \mathrm{Kg}+10.2 \mathrm{Kg}$

$=25.2 \mathrm{Kg}$

Dalam rancang bangun ini motor yang digunakan adalah motor bensin dengan putaran maksimal $3600 \mathrm{rpm}$ dan diameter poros pencampur $25.4 \mathrm{~mm}$, sehingga kecepatannya :

$$
\begin{aligned}
\mathrm{Vc} & =\frac{\pi \cdot d s . n}{1000} \\
& =\frac{3.14 .25 .4 .3600}{1000} \\
& =287.121 \mathrm{~m} / \mathrm{menit}
\end{aligned}
$$

Berdasarkan data-data diatas maka daya motor yang digunakan adalah :

$$
\begin{aligned}
P & =\frac{\text { Fs.Vc }}{4500} \\
& =\frac{25.2 .287,121}{4500} \\
& =1.6 \mathrm{Hp}
\end{aligned}
$$

Daya motor yang dibutuhkan adalah $1.6 \mathrm{Hp}$ jika menggunakan motor listrik, namun motor yang kami gunakan yaitu motor bensin yang dijual dipasaran dengan kekuatan 5.5 HP atau lebih besar dari daya yang dibutuhkan.

\section{Hasil Pengujian Alat \\ 1. Pengujian awal}

Sebelum dilakukan pengujian hasil pencampuran, terlebih dahulu dilakukan pengujian awal untuk menentukan kapasitas bahan pakan yang dapat diolah dalam satu kali proses pencampuran serta kecepatan putaran poros pengaduk yang akan digunakan. Dalam hal ini diberikan ruang untuk pergerakan pakan pada bagian atas bak penampung, sehingga volume ruang bebas untuk kapasitas satu 
kali proses pencampuran $1 / 2-1 / 4$ volume dari bak penampung dan massa bahan pakan, dalam hal ini jumlah massa pakan yang diuji sebanyak $15 \mathrm{~kg}, 16 \mathrm{~kg}$ dan $17 \mathrm{~kg}$.

Dengan memperhatikan secara visual proses pergerakan sirkulasi pakan yang paling baik, sehingga diperoleh kapasitas $15 \mathrm{~kg}$ pada putaran poros $55 \mathrm{Rpm}$ dan $16 \mathrm{~kg}$ pada putaran poros pengaduk $65 \mathrm{rpm}$, dan $17 \mathrm{~kg}$ pada putaran $75 \mathrm{rpm}$ untuk satu kali proses pengadukan. Sedangkan untuk massa bahan pakan sebanyak $>17 \mathrm{~kg}$ melebihi kapasitas dari ruang bebas bak pengaduk sehingga pencampuran menjadi berat dan bahan pakan menjadi terhambur.

\section{Pengujian Akhir}

Selanjutnya pengujian kinerja mesin dilakukan untuk menentukan kualitas hasil pencampuran bahan pakan ternak terbaik dengan menentukan 3 macam putaran $(55,65$, dan $75 \mathrm{rpm})$ dan 2 macam lama waktu proses pencampuran (4 dan 5 menit) untuk satu kali proses pencampuran.

Tabel 3. Data hasil pengujian pencampuran bahan pakan ternak

\begin{tabular}{|l|l|l|l|l|}
\hline $\begin{array}{c}\text { Putaran } \\
(\mathbf{r p m})\end{array}$ & $\begin{array}{c}\text { Massa Bahan Pakan } \\
(\mathbf{k g})\end{array}$ & Waktu Proses & $\begin{array}{c}\text { Kualitas Hasil } \\
(\mathbf{1 , 2 , 3})\end{array}$ & $\begin{array}{c}\text { Kapasitas Produksi } \\
(\mathbf{K g} / \mathbf{j a m})\end{array}$ \\
\hline 55 & 15 & 4 & 1 & 225 \\
\cline { 2 - 6 } & & 5 & 1 & 180 \\
\hline 65 & 16 & 4 & 2 & 240 \\
\cline { 2 - 6 } & & 5 & 3 & 192 \\
\hline 75 & 17 & 4 & 3 & 255 \\
\hline
\end{tabular}

Keterangan : 1. Kurang Merata; 2. Cukup Merata; 3. Merata

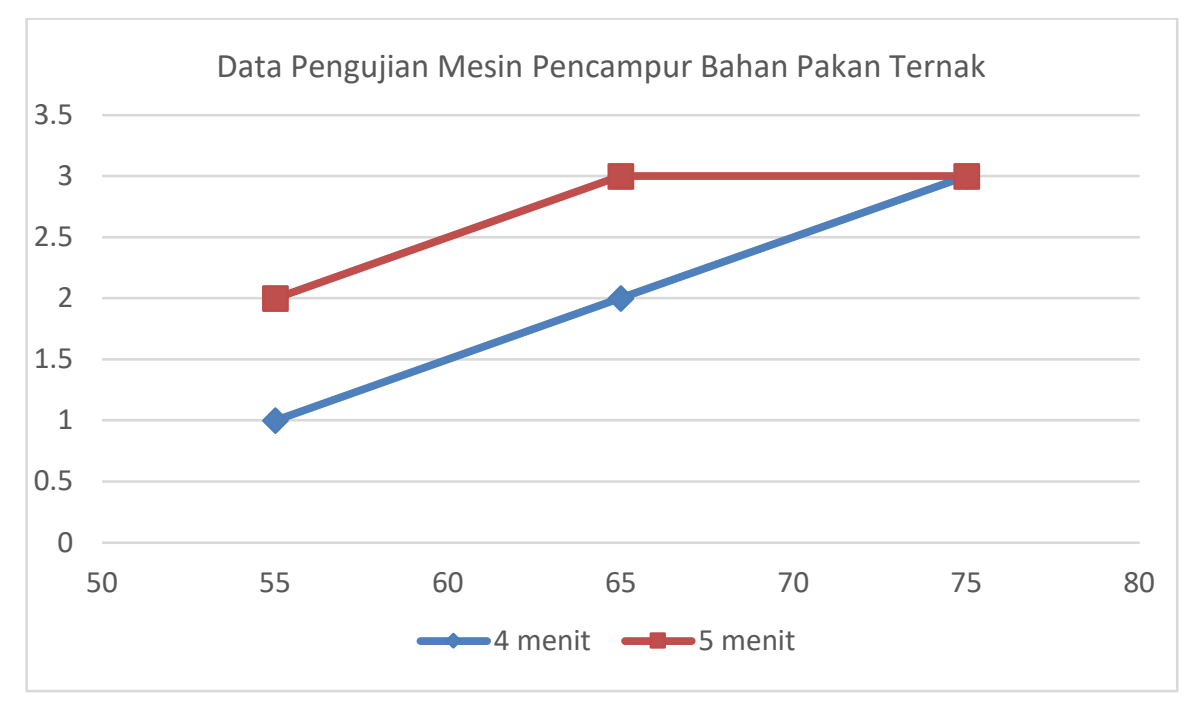

Gambar 6. Grafik data pengujian

Terlebih dahulu mesin pencampur pakan dihidupkan, kemudian mengukur rpm poros pengaduk menggunakan tachometer untuk kemudian di stabilkan pada putaran $55 \mathrm{rpm}$, selanjutnya bahan pakan dimasukkan kedalam bak penampung sebanyak $15 \mathrm{~kg}$ dengan komposisi bahan pakan berturut-turut, yaitu bahan jagung sebanyak $8 \mathrm{~kg}$, dedak halus sebanyak $3 \mathrm{~kg}$, bungkil kelapa sebanyak $2 \mathrm{~kg}$ dan tepung ikan sebanyak $2 \mathrm{~kg}$. waktu pencampuran masa percobaan dilakukan selama 4 dan 5 menit. Setelah proses pencampuran telah selesai sesuai waktu yang ditentukan kemudian keluarkan campuran pakan pada bak penampungan.

Kemudian dilakukan lagi pengujian dengan massa bahan pakan sebanyak $16 \mathrm{~kg}$ dengan komposisi bahan yaitu jagung sebanyak $10 \mathrm{~kg}$, dedak halus sebanyak $3 \mathrm{~kg}$, bungkil kelapa sebanyak 2 
$\mathrm{kg}$ dan tepung ikan sebanyak $2 \mathrm{~kg}$ pada kecepatan poros pengaduk $65 \mathrm{Rpm}$ dengan waktu pencampuran selama 4 menit dan 5 menit, setelah proses pencampuran telah selesai sesuai waktu yang ditentukan kemudian keluarkan campuran pakan pada bak penampungan.

Kemudian dilakukan lagi pengujian dengan massa bahan pakan sebanyak $17 \mathrm{~kg}$ dengan komposisi bahan yaitu jagung sebanyak $11 \mathrm{~kg}$, dedak halus sebanyak $3 \mathrm{~kg}$, bungkil kelapa sebanyak 2 $\mathrm{kg}$ dan tepung ikan sebanyak $2 \mathrm{~kg}$ pada kecepatan poros pengaduk $65 \mathrm{Rpm}$ dengan waktu pencampuran selama 4 menit dan 5 menit, setelah proses pencampuran telah selesai sesuai waktu yang ditentukan kemudian keluarkan campuran pakan pada bak penampungan.

\section{Biaya Manufaktur}

1. Biaya bahan langsung

Jumlah keseluruhan untuk biaya bahan langsung dari mesin pencampur bahan pakan ternak adalah Rp. 3.945.000,- rinciannya dapat dilihat pada tabel 4 .

Tabel 4. Biaya bahan langsung

\begin{tabular}{|c|c|c|c|c|c|}
\hline No & Nama Barang & Ukuran & Harga/unit & Banyak & Jumlah \\
\hline 1 & Besi Siku L & $50 \times 50 \times 6 \mathrm{~m}$ & Rp. $100.000,-$ & 3 & $300.000,-$ \\
\hline 2 & Plat Baja & $3 \mathrm{~mm} 1.2 \times 2,4 \mathrm{~m}$ & $610.000,-$ & 1 & $610.000,-$ \\
\hline 3 & Besi As ST-42 & 1 inci $x 2 \mathrm{~m}$ & $165.000,-$ & 1 & $165.000,-$ \\
\hline 4 & Pipa Stainless & 1 inci $x 60 \mathrm{~cm}$ & $140.000,-$ & 1 & $140.000,-$ \\
\hline 5 & Besi As monel & $10 \mathrm{~mm} \times 3 \mathrm{~m}$ & $165.000,-$ & 1 & $165.000,-$ \\
\hline 6 & Sproket & $14 \mathrm{~T}$ & $15.000,-$ & 3 & $45.000,-$ \\
\hline 7 & Sproket & $30 \mathrm{~T}$ & $100.000,-$ & 1 & $10.000,-$ \\
\hline 8 & Engsel Bubut & - & $10.000,-$ & 2 & $20.000,-$ \\
\hline 9 & Bearing UCP 205 & Poros 1 inci & $30.000,-$ & 2 & $60.000,-$ \\
\hline 10 & Roda karet & 5 inci & $35.000,-$ & 2 & $70.000,-$ \\
\hline 11 & Rantai motor & $428 \mathrm{H}$ & $65.000,-$ & 2 & $130.000,-$ \\
\hline 12 & Clip Pengunci & Ukuran M & $25.000,-$ & 2 & $50.000,-$ \\
\hline 13 & Reduser & $1: 20$ & $850.000,-$ & 1 & $850.000,-$ \\
\hline \multirow{3}{*}{14} & \multirow{3}{*}{ Baut, Mur dan Ring } & Standar ISO (M8) & $1.000,-$ & 10 & $10.000,-$ \\
\hline & & Standar ISO (M10) & $1.500,-$ & 8 & $12.000,-$ \\
\hline & & Standar ISO (M12) & $2.000,-$ & 4 & $8000,-$ \\
\hline 15 & Motor Bensin & $5.5 \mathrm{HP}$ & Rp. 1.300.000,- & 1 & RP. $1.300 .000,-$ \\
\hline \multicolumn{5}{|c|}{ Jumlah total biaya langsung } & RP. 3.945.000,- \\
\hline
\end{tabular}

\section{Biaya tenaga kerja}

Biaya tenaga kerja dapat diketahui dengan mengalikan waktu pengerjaan dengan upah/jam, upah tenaga kerja dari setiap bulan ditentukan berdasarkan Upah Minimum Provinsi Sulawesi Selatan Nomor 2628/X/Tahun 2017 sebanyak Rp. 2.650.000,- tiap bulannya. Untuk biaya tenaga kerja dari setiap pengerjaan dapat dilihat pada tabel 5 .

Tabel 5. Biaya tenaga kerja

\begin{tabular}{|c|c|c|c|c|c|}
\hline No & Jenis Pengerjaan & Waktu Pengerjaan & Upah/Bulan & Upah/Jam & Upah Pengerjaan \\
\hline 1. & Potong plat & 1 jam & \multirow{6}{*}{ Rp. $2.650 .000,-$} & \multirow{6}{*}{ Rp. 13.000,- } & 13.000 \\
\hline 2. & Gerinda & 3 jam & & & 39.000 \\
\hline 3. & Bubut & 1 jam & & & 13.000 \\
\hline 4. & Drilling & 3 jam & & & 39.000 \\
\hline 5. & Las & $12 \mathrm{jam}$ & & & $\begin{array}{ll}\text { Rp. } & 156.000 \\
\end{array}$ \\
\hline 6. & Pengerolan & 1 jam & & & 13.000 \\
\hline \multicolumn{5}{|c|}{ Jumlah Total Biaya Tenaga Kerja } & Rp. $\quad$ 273.000 \\
\hline
\end{tabular}




\section{Biaya bahan tidak langsung}

Biaya bahan tidak langsung dapat dilihat pada tabel 6.

Tabel 6. Biaya bahan tidak langsung

\begin{tabular}{|c|c|c|c|c|c|}
\hline No & Nama Mesin & Nama Bahan & *Harga/unit (Rp) & Jumlah & Jumlah (Rp) \\
\hline \multirow{7}{*}{1.} & \multirow{7}{*}{ Bubut } & Mata bor $15 \mathrm{~mm}$ & $32.000,-$ & 1 buah & $220.000,-$ \\
\hline & & Mata bor $18 \mathrm{~mm}$ & $38.000,-$ & 1 buah & $38.000,-$ \\
\hline & & Mata bor $22 \mathrm{~mm}$ & $47.000,-$ & 1 buah & $47.000,-$ \\
\hline & & Mata bor $26 \mathrm{~mm}$ & $55.000,-$ & 1 buah & $55.000,-$ \\
\hline & & Oli dromus & $65.000,-$ & 1 Liter & $65.000,-$ \\
\hline & & Kuas & $4.000,-$ & 1 buah & $4.000,-$ \\
\hline & & Majun & $12.000,-$ & $1 \mathrm{~kg}$ & $12.000,-$ \\
\hline \multirow{6}{*}{2.} & \multirow{6}{*}{ Las } & Elektroda & $135.000,-$ & $1 \mathrm{dos}$ & $135.000,-$ \\
\hline & & Elektroda Stainless & $3.000,-$ & 40 buah & $120.000,-$ \\
\hline & & Elektroda $2 \mathrm{~mm}$ & $45.000,-$ & $1 \mathrm{~kg}$ & $45.000,-$ \\
\hline & & Topeng Las & $28.000,-$ & 1 buah & $28.000,-$ \\
\hline & & Sarung tangan & $65.000,-$ & 1 pasang & $65.000,-$ \\
\hline & & Palu & $40.000,-$ & 1 buah & $40.000,-$ \\
\hline \multirow{4}{*}{3.} & \multirow{4}{*}{ Drill } & Mata Bor $6 \mathrm{~mm}$ & $10.000,-$ & 1 buah & $10.000,-$ \\
\hline & & Mata Bor $7 \mathrm{~cm}$ & $13.000,-$ & 1 buah & $13.000,-$ \\
\hline & & Mata Bor $8 \mathrm{~mm}$ & $15.000,-$ & 1 buah & $15.000,-$ \\
\hline & & Mata Bor $12 \mathrm{~mm}$ & $25.000,-$ & 1 buah & $25.000,-$ \\
\hline \multirow{4}{*}{4.} & \multirow{4}{*}{ Gerinda } & Batu gerinda asah & $6.000,-$ & 6 buah & $36.000,-$ \\
\hline & & Batu gerinda potong & $45.000,-$ & $1 \mathrm{dos}$ & $30.000,-$ \\
\hline & & Batu gerinda poles & $8.000,-$ & 3 buah & $24.000,-$ \\
\hline & & Mata gerinda sikat & $23.000,-$ & 1 buah & $23.000,-$ \\
\hline \multirow{5}{*}{5.} & \multirow{5}{*}{ Pengecatan } & Cat & $50.000,-$ & 2 kaleng & $100.000,-$ \\
\hline & & Kuas & $6.000,-$ & 2 buah & $12.000,-$ \\
\hline & & Thinner & $10.000,-$ & 1 botol & $10.000,-$ \\
\hline & & Dempul & $17.000,-$ & 2 kaleng & $34.000,-$ \\
\hline & & Clear & $24.000,-$ & 1 kaleng & $24.000,-$ \\
\hline \multicolumn{5}{|c|}{ Jumlah Total biaya bahan tidak langsung } & Rp. 1.230.000,- \\
\hline
\end{tabular}

Keterangan : * Harga pada bulan maret sampai september 2018

\section{Biaya tidak langsung}

Biaya tidak langsung dapat dilihat pada tabel 7.

Tabel 7. Biaya tidak langsung

\begin{tabular}{|c|l|r|}
\hline No & Biaya tidak langsung & Harga (Rp) \\
\hline 1. & Biaya bahan tidak langsung & $1.230 .000,-$ \\
\hline 2. & Biaya listrik & $43.820,-$ \\
\hline 3. & Biaya penyusutan mesin & $28.213,-$ \\
\hline Total & Rp. 1.302.033,- \\
\hline
\end{tabular}

Berdasarkan data diatas biaya tidak langsung dari proses pengerjaan mesin pencampur bahan pakan ternak dapat diketahui dengan menjumlahkan biaya bahan tidak langsung, tarif listrik dan biaya penyusutan mesin yaitu Rp 1.302.033,-

Biaya untuk memproduksi mesin pencampur bahan pakan ternak dapat diketahui dari jumlah biaya bahan langsung, biaya tenaga kerja dan biaya tidak langsung. 
39 Muhammad Iswar, Abdul Salam, Lukman Taufik, Amirul Haj, Muh. Iqbal. Modifikasi Mesin Pencampur Bahan Pakan Ternak

\section{Biaya Manufaktur}

Biaya total manufaktur dapat dilihat pada tabel 8 .

Tabel 8. Biaya manufaktur

\begin{tabular}{|c|l|c|}
\hline No & Biaya manufaktur & Harga \\
\hline 1. & Biaya bahan langsung & Rp. 3.945.000,- \\
\hline 2. & Biaya tenaga kerja & Rp. 273.000,- \\
\hline 3. & Biaya tidak langsung & Rp. 1.302.033,- \\
\hline Jumlah & Rp. 5.520.033,- \\
\hline
\end{tabular}

Dilihat dari hasil perhitungan diatas telah diketahui biaya untuk memproduksi 1 unit mesin pencampur bahan pakan ternak yaitu Rp. 5.520.033,-

\section{E. Pembahasan}

Dari hasil pengujian yang telah dilakukan, parameter keberhasilan pengujian pencampuran bahan pakan ternak dapat dilihat dengan membandingkan hasil pencampuran pakan ternak pada mesin sebelumnya, yakni mesin pencampuran bahan pakan ternak menggunakan v-belt dan pully, dan setelah mesin dimodifikasi yakni dengan menggunakan sproket, rantai dan reduser. Untuk mesin menggunakan v-belt dan pully pada putaran $65 \mathrm{rpm}$ dengan waktu proses pencampuran selama 5 menit, kualitas hasil pencampuran kurang merata, hal ini disebabkan poros pencampur tidak bekerja secara maksimal karena terkadang terjadi slip pada poros dan pully pengaduk dikarenakan $v$-belt tidak mampu mencengkram pully pengaduk untuk melakukan proses pencampuran. Namun pada putaran 70 Rpm baru dapat menhasilkan campuran pakan yang merata dengan massa campuran $15 \mathrm{~kg}$ selama 5 menit.

Sementara untuk mesin yang telah dimodifikasi menggunakan sproket, rantai dan reduser, tidak terjadi lagi slip seperti pada mesin sebelumnya pada putaran $65 \mathrm{Rpm}$, sehingga dilakukan pengujian pencampuran dengan massa bahan pakan $15 \mathrm{~kg}$ dengan waktu pencampuran selama 4 menit didapatkan hasil pencampuran yang sudah cukup merata dan pengujian dengan waktu 5 menit didapatkan hasil pencampuran yang merata.

Berdasarkan data tersebut maka jenis transmisi mesin dan waktu terbaik yang dipilih dalam mencampur bahan pakan ternak yaitu dengan menggunakan transmisi sprocket, rantai dan reduser dengan putaran $55 \mathrm{rpm}$ dan waktu pencampuran 5 menit diperoleh hasil campuran yang merata dengan kapasitas produksi $180 \mathrm{~kg} / \mathrm{jam}$. Hasil ini jauh lebih baik bila dibandingkan dengan alat sebelumnya yang menghasilkan bahan pakan ternak yang kurang merata pada putaran $55 \mathrm{rpm}$.

Untuk lebih mengoptimal kapasitas kinerja mesin pencampur bahan pakan ternak ini, maka dilakuakan lagi pengujian dengan massa bahan pakan sebanyak $17 \mathrm{~kg}$, dari hasil pengujian tersebut diperoleh hasil kualitas dengan waktu pencampuran 4 menit yang cukup merata sedangkan dengan waktu pencampuran 5 menit diperoleh hasil yang merata.

\section{KESIMPULAN}

Berdasarkan hasil modifikasi mesin pencampuran bahan pakan ternak ini diperoleh beberapa kesimpulan sebagai berikut :

a. Dengan desain mesin yang lebih sederhana ini, dapat mempermudah peternak untuk memindah tempatkan mesin tersebut dikarenakan adanya penambahan roda dan ukuran mesin yang lebih ramping, serta dapat dibongkar pasang.

b. Dengan adanya perubahan pada pemindah daya (transimisi) dengan menggunakan sproket, rantai dan reduser tidak terjadi lagi slip, sehingga dari hasil pencampuran bahan pakan ternak sebanyak $17 \mathrm{~kg}$ pada putaran $65 \mathrm{rpm}$ diperoleh hasil yang merata dengan waktu pencampuran selama 5 menit atau kapasitas campuran maksimum $204 \mathrm{~kg} / \mathrm{jam}$. 


\section{DAFTAR PUSTAKA}

[1] Ridwan, Muhammad. dkk. "Perancangan dan Pembuatan Mesin Pencampur Pakan Ternak Kapasitas Maksimum 50 kg/jam”. 2002. Tugas Akhir. Makassar: Program Studi Teknik Mesin Polteknik Negeri Ujung Pandang.

[2] Muataatiah dkk. "Modifikasi Alat Pencampur Pakan Ternak". 2008. Tugas Akhir. Makassar; Program Studi Teknik Mesin Politeknik Negeri Ujung Pandang.

[3] Ahmad, AA, Erwin,B, \& Hafiz, A. "Mesin Pencampur Bahan Pakan Ternak". 2017. Tugas Akhir. Politeknik Negeri Ujung Pandang. Makassar.

[4] Pramono, Catur. "Kajian Kinerja Mesin Pencampur Pakan Ternak Menggunakan Daya 0,25 HP". Wahana Ilmuwan, 2016, 2.2.

[5] Wardjito, Wardjito; Rahmanda, Jun Dwiky. "Perencanaan Mesin Pencampur Pakan Ternak Berupa Rumput Dengan Tetes Tebu Dengan Kapasitas 750 kg/15 Menit”. Wahana Teknik, 2014, 3.1 .

[6] Kurniasih, Dewi, et al. "Pembuatan Pakan Ternak dari Limbah Cangkang Kerang di Desa Bulak Kenjeran Surabaya”. In: Seminar Master PPNS. 2017. p. 159-164.

[7] Salam, Abdul; Iswar, Muhammad. "Pengembangan Desain Mesin Pencampur Bahan Pakan Ternak". In: Seminar Nasional Hasil Penelitian \& Pengabdian Kepada Masyarakat (SNP2M). 2018.

[8] Prasetya, Yuli, et al. "Penerapan Crusher And Mixing Machine Pakan Ternak Berbasis PLC Pada Peternak Ayam Petelur di Desa Mojorejo Kabupaten Magetan". J-ADIMAS (Jurnal Pengabdian kepada Masyarakat), 2019, 7.2. 